\title{
A Plethora of Atmochemical Studies: Ozone Layer Depletion and Its Consequences on Socio-Economic Development in Nigeria
}

\author{
Darma, M. R. ${ }^{1}$ and Kankara, I. A ${ }^{2}$
}

\begin{abstract}
Effects of Atmospheric geochemistry and Ozone layer depletion on the Socio-Economic development in Nigeria were explored in this paper, while adaptations of developmental practices that could be adapted so as to mitigate impending disaster were proffered. The study used both Primary and Secondary data on the nature of atmospheric conditions and its negative effects to the Environment in Nigeria. The result revealed that Ozone layer depletion really exists and has many adverse effects on the socioeconomic development of the Country. The study also revealed that Citizens living in the Arid and semi-arid parts of the Country are more prone to the changes.
\end{abstract}

Keywords-Atmospheric Geochemistry, Ozone Layer, Depletion, Socio-Economic Development, Nigeria.

\section{INTRODUCTION}

$\mathrm{S}$ EVERAL scholars attempted to define the concept of climate, for example [1] referred to it as the average of weather conditions, indeed up to 1950 , and particular between 1900 and 1950, not much was thought of climatic events and their consequences, mainly because there were relatively not much adverse consequences of these events on agriculture, particularly on a global scale. At least the population was well fed and the stomach well catered for. Incidentally, in Europe and America, historical records of climatic data gave scientific support to the concept of constancy in climate.

However, recent events all over the world have indicated that the climate cannot and should not be regarded as constant and that for all practical purposes, the statistics required to specify climate comprise not only averages but also extremes and frequencies of occurrence of the various characteristics that arc of interest to man [1]. It is thus clear that defining climate, the total experience of weather at any place over some specific period of time must be considered. Thus, it is out of place to continue to have an idea that if a long enough series of observations could be amassed at a location, it would produce a 'climatic' normal and an average value of each climate element which could be of use for any practical considerations [1].

In essence, far from being average of weather, the climate is always changing on a variety of time scales. The underlying

\footnotetext{
${ }^{1}$ Pleasant Engineering and Technical Services Katsina

${ }^{2}$ Department of Geography and Regional Planning, Federal University DutsinMa.
}

mechanisms for the various changes which occur in the climate are related to the restless nature of the atmosphere, the range of whose activity spans from very local to the very global scales, the global scales include the long-lived general atmospheric circulations. Between these local and global scales lie the meso-scale transitional activities with influence zones and regions at continental or oceanic scale. Indeed, it is the various micro-meso and macro-scale atmospheric processes which produce the various changes and variations in weather and climate. It is pertinent to note that the global climate system also involves in addition to the atmosphere, the oceans and other surface waters, the world of ice masses, the surface soil and vegetation and geophysical features of the earth [2].

Another noticeable feature of the climate system is the temporal dimension of events in the climatic complex which involves climatic revolutions or climatic changes at time scales greater than 1,000 years. The second results in climatic fluctuations at time scales of $10-1,000$ yeas, while the third category results in erratic pulsation, usually of less than ten years duration. The fourth and final category results in maninduced climate fluctuations whose times scales may be ten years or less. The first two categories are of significance for practical applications of climate to human society [3].

This paper seeks to identify how we got to this point of imminent catastrophe, how vulnerable Nigerians are, especially those that live in environment disadvantaged areas. The effects of this change on the socio-economic development of the people will also be explored while adaptation developmental practices that can be adopted in order to mitigate impending disaster will be proffered [4]. The study made use of both primary and secondary data which includes a questionnaire survey of the perception of the impact of climate change phenomena as well as relevant already published data on the nature and effect of climate change in Nigeria.

\section{THE STUDY AREA}

Nigeria is located in western Africa on the Gulf of Guinea and has a total area of $923,768 \mathrm{~km}^{2}(356,669 \mathrm{sq} \mathrm{mi})$ It is situated in the West African region and lies between longitudes 3 degrees and 14 degrees and latitudes 4 degrees and 14 degrees (see figure 1). It has a land mass of 923,768 sq.km. It shares a 4,047-kilometre $(2,515 \mathrm{mi})$ border with Benin $(773 \mathrm{~km})$, Niger $(1497 \mathrm{~km})$, Chad $(87 \mathrm{~km})$, and Cameroon $(1690 \mathrm{~km})$, and has a coastline of at least $853 \mathrm{~km}$. 
Nigeria lies between latitudes $4^{\circ}$ and $14^{\circ} \mathrm{N}$, and longitudes $2^{\circ}$ and $15^{\circ} \mathrm{E}$. The highest point in Nigeria is Chappal Waddi at $2,419 \mathrm{~m}(7,936 \mathrm{ft})$. The main rivers are the Niger and the Benue, which converge and empty into the Niger Delta. This is one of the world's largest river deltas, and the location of a large area of Central African mangroves.

Nigeria has a varied landscape. The far south is defined by its tropical rainforest climate, where annual rainfall is 60 to 80 inches $(1,500$ to $2,000 \mathrm{~mm})$ a year. In the southeast stands the Obudu Plateau. Coastal plains are found in both the southwest and the southeast. This forest zone's most southerly portion is defined as salt water swamp, also known as a mangrove swamp because of the large amount of mangroves in the area. North of this is fresh water swamp, containing different vegetation from the salt water swamp, and north of that is rainforest. It is found in the Tropics, where the climate is seasonally damp and very humid. Nigeria is affected by four climate types; these climate types are distinguishable, as one moves from the southern part of Nigeria to the northern part of Nigeria through the middle belt.

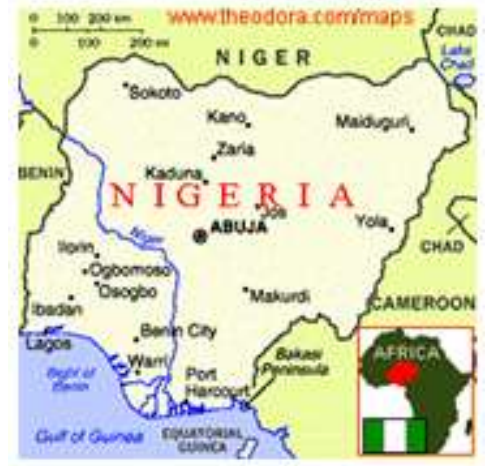

Fig. 1: Map of Nigeria showing the States

In line with rainfall distribution, a wetter south and a drier northern half, there are two broad vegetation types: Forests and Savanna. There are three variants of each, running as near parallel bands east to west across the country. Forests Savanna Saline water swamp Guinea Savanna Fresh water swamp Sudan Savanna Tropical (high) evergreen Sahel Savanna Rainforest. There is also the mountain vegetation of the isolated high plateau regions on the far eastern extremes of the country (Jos, Mambilla, Obudu). The savanna, especially Guinea and Sudan, are the major grains, grasses, tubers, vegetable and cotton growing regions.

The Tropical evergreen rain forest belt bears timber production and forest development, production of cassava; and plantation growing of fruit trees-citrus, oil palm, cocoa and rubber, among others.

Katsina metropolis (city) is situated between Latitudes $11^{\circ}$ $18^{\prime} \mathrm{N}$ and $13^{\circ} 22^{\prime} \mathrm{N}$, and Longitudes $6^{\circ} 52^{\prime} \mathrm{E}$ and $9^{\circ} 20^{\prime} \mathrm{E}$. It was built on a spur of land between Ginzo and Tilla streams which flows in a north-easterly direction, and is at a narrow neck of water shed between the Gada and Tagwai River Basin (Figure 2.1). Katsina is an ancient old City that was formerly a City State surrounded by City wall of 21 kilometers in diameter/length Katsina is a local government Headquarter and the capital city of Katsina State. It is one of the 36 States that comprises the Federal Republic of Nigeria [5]. The city is moderately populated with about 700,000 persons/settlers been recent estimates mainly as a result of natural increase and migration from other cities that were affected by insecurity in northern Nigeria. The climate is Tropical Continental type, classified according to Kopen's Climate Classification as AW, with long dry season and short wet season.

Vegetation type is Sudan Savannah with short scattered trees and grasses. Most of the vegetation is affected by human activities such as deforestation for fuel wood and clearance of vegetation for residential purpose.

The geology of the area governs the nature of river flowage. The project area lies within the Nigerian Basement Complex which is divided into crystalline basement of migmatites and gneisses. The crystalline basement initially behaved as one tectonic unit, but later experienced two periods of syntectonic metamorphisms with deformations in two successive phases called the Intense Alpine type's deformations. The deformations took place during the Pan African Orogeny which were accompanied by metamorphism, granitization and feldspatization. The first tectonics resulted in extensive migmatization of the basement but was further differentiated during the second tectonics to produce homogenous gneiss and intrusive granites.

The migmatites and gneiss represent the oldest rocks in the basement complex. There are at least two generations of migmatitic gneiss of widely different ages within the study area. The migmatitic gneiss underlie mica schist, dipping south-east at between 270 and 430 with most outcrops observed in stream channels [6]. The mica schists are generally fissile dark-grey to greenish grey in color and weather to a silvery to a light grey colored with red iron- oxide stains on its fissile surfaces.

\section{Climate Change CONCEPT}

It is now established that humanity is altering the concentration of greenhouse gases and aerosols, both of which influence, and are influenced by climate. Recently, and especially over the past three or four decades, the issue of global climate change due to the greenhouse effects, including global warming and sea level rise have been a subject of scientific discussions and public debate. Indeed, it is now well recognized that the human factor has become very significant in the balance of forces that determine the earth's climate. In particular, it is the consensus of opinion that the atmospheric concentration of a number of gases are known to be increasing and that some of these gases have important effects in causing the greenhouse gases, carbon dioxide $\left(\mathrm{CO}_{2}\right)$ has potentially been the most effective in changing the earth's climate, and has been responsible for over $50 \%$ of the enhanced greenhouse effect in the past and is likely to remain so in the future. Other greenhouse gases include nitrous oxide $\left(\mathrm{N}_{2} \mathrm{O}\right)$, methane $\left(\mathrm{CH}_{4}\right)$, chlorofluorocarbons (CFCs), ozone $\left(\mathrm{O}_{3}\right)$ and aerosols [7]. The atmospheric concentration of the greenhouse gases have grown significantly since pre-industrial times (about 1720 A.D.) for example, $\mathrm{CO}_{2}$, increased from about 280 to almost 360 ppmv, $\mathrm{CH} 4$ from 700 to $1720 \mathrm{ppbv}$ and $\mathrm{N}_{2} \mathrm{O}$ from about 275 to about 310 ppbv. 
TABLE 1: Summary of Emissions from the Nigerian Energy Sector 2003 emissions

\begin{tabular}{|l|c|c|c|c|c|c|c|}
\hline \multicolumn{1}{|c|}{ Sector } & $\begin{array}{c}\text { Total Energy } \\
\text { Consumptions\% }\end{array}$ & $\mathbf{C O}_{\mathbf{2}}$ & $\mathbf{C H}_{\mathbf{4}}$ & $\mathbf{N}_{\mathbf{2}} \mathbf{O}$ & $\mathbf{C O}$ & No. & NMVOC \\
\hline Public Electricity & 100.9 & 5686.3 & 0.01 & 0.20 & 1.30 & 5.82 & 0.00 \\
\hline Petroleum Refinery & 765.9 & 6098.9 & 0.61 & 2.91 & 28.34 & 4.14 & 12.10 \\
\hline Industry & 18.3 & 1435.9 & 0.05 & 0.12 & 0.30 & 3.06 & 0.04 \\
\hline Transport & 545.1 & 38473.4 & 12.07 & .86 & 4728.99 & 322.47 & 896.19 \\
\hline Small Combustion & 738.5 & 4700.9 & 445.21 & 3.36 & 4139.25 & 127.87 & 4.71 \\
\hline Fugitives & 5.2 & 58080.0 & 1018.23 & 0.00 & 4224.00 & 28.99 & 951.10 \\
\hline Total & $\mathbf{2 1 8 3 . 4}$ & $\mathbf{1 1 5 1 8 2 . 2}$ & $\mathbf{1 4 7 6 . 2 1}$ & $\mathbf{7 . 4 7}$ & $\mathbf{1 3 1 2 5 . 5 3}$ & $\mathbf{5 0 1 . 8 9}$ & $\mathbf{1 8 6 4 . 2 6}$ \\
\hline
\end{tabular}

Source: FGN (2003) Nigeria's First National communication.

TABLE 2: Per Capita Sectoral and Gross Emissions in Nigeria for 2003

\begin{tabular}{|c|c|c|c|c|c|c|}
\hline \multirow[b]{2}{*}{ Sector } & \multicolumn{6}{|c|}{2003 Specific Emissions } \\
\hline & $\begin{array}{l}\text { CO2 (kg } \\
\text { C/cap) }\end{array}$ & $\begin{array}{l}\text { CH4 (kg } \\
\text { C/cap) }\end{array}$ & $\begin{array}{l}\text { N2O (kg } \\
\text { C/cap) }\end{array}$ & $\begin{array}{l}\text { CO (kg } \\
\text { C/cap) }\end{array}$ & $\begin{array}{l}\text { NOx (kg } \\
\text { C/cap) }\end{array}$ & $\begin{array}{l}\text { NMVOC (kg } \\
\text { NMVOC/Cap) }\end{array}$ \\
\hline Energy & 324.65 & 11.44 & 0.05 & 54.26 & 1.58 & 19.27 \\
\hline Industry & 4.96 & 0.00 & 0.00 & 0.00 & 0.00 & 3.79 \\
\hline Solvent use & 0.00 & 0.00 & 0.00 & 0.00 & 0.00 & 0.00 \\
\hline Agric & 0.00 & 17.17 & 0.03 & 14.83 & 0.47 & 0.00 \\
\hline Luc & 212.92 & 0.14 & 0.00 & 0.67 & 0.01 & 0.00 \\
\hline Wastes & 0.00 & 16.21 & 0.00 & 0.71 & 0.01 & 0.00 \\
\hline Total & 542.54 & 45.97 & 0.08 & 70.46 & 2.07 & 23.06 \\
\hline
\end{tabular}

Source: FGN (2003) Nigeria's First National Communication

\section{GLOBAL WARMING IMPLICATIONS FOR THE SOCIO- ECONOMIC DEVELOPMENT OF NIGERIA}

Although there are no globally compulsory development models for mitigating g1obal warming, it is imperative for duty-of-Care that governments all over world including Nigeria engage in governance practices that guarantee sustainable development. In developed countries, for instance, economic and social planning is characterized by efficient allocation and use of resources to achieve sustainable and buoyant economic and social life for their citizens, However, economic and social planning in underdeveloped and developing countries such as Nigeria is characterized by Policy inconsistency and implementation irregularities. These countries (especially in Africa) are inefficient in the deployment of natural and other development resources; a situation which results in extreme disparities in the distribution of incomes and political power [8]. This phenomenon frequently generates poverty, illiteracy, disease, political agitation and conflict.

Since Nigeria does not exist in global isolation, there are some negatives recent impacts of global warming around the country which include:

a. High surface temperature regimes have resulted in climate-driven heat stress to huge populations around the country.

b. Increase in drought-like conditions especially in the extreme Northern parts has created negative impact on food and agricultural production with resultant reduction of Farm-Income which in turn results in increased poverty, hunger and starvation.

c. There is high frequency of incidences of coastal erosion which destroys Housing Assets and farms lands in littoral communities of Southern Nigeria. Gully erosion in Eastern Nigeria has also impacted negatively on habitat assets and general economic life of the communities in that region. d. Desertification has moved inland progressively and several kilometers of desert encroachment has been witnessed in Northern parts of Nigeria in the last 3 decades.

e. Increased incidence of flooding further complicates the poor sanitation infrastructure thereby resulting in high incidence of water related diseases like cholera/sectorborne diseases like malaria around the country.

f. The reduction in the perimeter size arid depth levels of important lakes like Lake Chad and the reduction in river water through-put in some of the rivers shows that inland water bodies in Nigeria are drying up gradually which has high negative impact domestic usage of water [6].

g. Also the River Niger which used to be the reliable source of Kanji Dam feedstock for the production of electricity has witnessed a great level of dryness in the past 20 years (although the incidence of excessive damming of the river by member countries of the MANO-RIVERUNION has contributed to this phenomenon.

h. There is also a systematic negative impact on eco-system and Biodiversity.

All of the forgoing effects of Global Warming have serious negative impact on the socio and political environment in Nigeria including explosive urbanization due to shortage of Arabic land, community vulnerability, human individual behavior, individual vulnerability and associated Emotional complexities.

Also, the health effects of Global Warming on the health of Nigerians is unquantifiable of the climate change events enumerated above base consequences on the health and livelihood $\mathrm{f}$ the citizens of Nigeria.

This situation is further compounded by the absence of a well articulated response plan in the country and the behavior of Corporate Organizations in Nigeria have proved to be negatively impactful on both Natural and Human Resources around the country. The ordinary case of Gas flares in the Niger Delta is a serious case of consideration. For instance, 
Nigeria have been setting targets for zero Gas Flare over the past 20 years, but unfortunately the oil companies operating in Nigeria have refused to comply despite knowing the importance of targets and compliance on Global Warming issues, Ordinarily, compliance to such laws in their own home countries is non-negotiable.

Similarly, manufacturing industries and the transport sector in Nigeria excessively consume diesel oil (AGO) and other high carbon emitting heavy oils; and have encountered a lot of challenges in utilizing cleaner and greener fuels for some decades now (for instance in the mid 1980s, in the NNPC tried to encourage Nigerians to utilize gas for running their vehicles and actually installed gas conversion facilities in Warri and some other parts of Nigeria but this initiative has since been discontinued. Also the erratic nature of electricity supply in Nigeria have compelled a lot of domestic use of high carbon emitting generating sets in homes and offices; which frequently results in high cost of living and high cost of doing business for many organizations. Despite the foregoing problems Nigeria still have the opportunity of keeping hope alive by formulating a well articulated socio-economic response plan to mitigate effects of Global warming. However, this requires a well defined concerted effort from all stakeholder including the academia, politicians and administrators, teachers, professional bodies and youths, including rural dwellers [9].

A revolutionary agro-energy program can be a starting point of this new direction and Nigeria has all the prerequisites for successful implementation of a sustainable development agenda.

\section{ROLE OF STAKEHOLDERS}

As mentioned earlier there is need for stakeholders to formulate a formidable Global warming response plan that is multi disciplinary such as the simple solution package that is recommended in this paper which hinges primarily on energy efficiency, water development, Agricultural expansion, Transportation, Environment and Rural Poverty Eradication.

\subsection{Energy}

In the area of Energy efficiency, the Ministry of Energy should design and implement a strategic energy plan which seeks to reduce portfolio burden on one single hydrocarbon resource; (which promotes pollution in the $\mathrm{CO}_{2}, \mathrm{NO}_{\mathrm{x}}$ and VOC's category). This ne energy plan should adopt an Energy Mix in which Renewable Energy sources such as solar, wind and Biofuels are adequately harnessed and used to control Global Warming. Renewable Energy Fuels are classified as "Clean Fuels" apart from originating from Renewable Resources [10].

Drastic measures such as pack and go sanctions need to be taken against oil companies that do not comply with a final Zero-Flare order. Also the process of improving electricity supply through the use of Gas should be accelerated in order to minimize the use of power generators whose exhaust emission also contribute to $\mathrm{CO}_{2}$ pollution.

\subsection{Agriculture and Water Resources}

Agriculture is the centerpiece of this agro-energy solution plan because both the bio fuels initiative and the Poverty Eradication plan resolve around it. The Ministry of Agriculture should undertake a massive agricultural expansion program through ACREAGE EXPANSION of up to 50\% of current cultivation portfolio and this expansion should he used for the cultivation of all categories of mandate crops in order to produce both the required feed stock for the BIOFUELS program and also increase FOOD production for human consumption food security. This scheme can be used to provides jobs and economic empowerment to the multitude of SME farmers who will grow cassava/sugarcane for the Biofuels program and Rice/other staples for the accelerated food expansion program. As in many other parts of the world, agriculture in Nigeria only supplies food, but also provides a fat of opportunities for employment. It is also significant as a source of raw materials for industry and as major source of income for farmers and others who depend on agricultural products for commercial purposes.

Although crude oil is now by far the most important source of government revenue in Nigeria about $70 \%$ of the labor force is still employed in agriculture. Indeed, the low per capital income reflect both the continuing reliance of most Nigerians on traditional agriculture [11]. Most Nigerian are still peasant farmers producing their own food crops and deriving income from one or more cash crops as well as from the sale of surplus food crops. Mixed cropping on fields which rarely exceed 2ha is characteristic of agriculture in Nigeria.

The seasonal nature of much of the Farming work shows the significance of the climatic factor with the farmer and his assistant's ability to cope with the busiest agricultural season or otherwise often setting a limit on the area which they can cultivate effectively. In general, the work of the farmer is strongly related to the seasons and productivity is affected by the rains: in this regard, the issue of the climatic dilemma comes into play. No doubt, weather and climate to a large estent, control agricultural characteristics including plant growth, length of the growing season and the productivity of plants and animals. Thus, the successes of agricultural operations depend very much on man's understanding of the weather.

The most critical factor in the trend of agricultural production is rainfall and particularly, the variability and unreliability characteristics. With the Sahelian droughts of the 1970 s, for instance, food production dropped by over $60 \%$ in the northern parts of Nigeria. Similar characteristics were found in other parts of the country [6]. The water resources ministry should revisit the concept of Inter - Basin -Water Transfer-Schemes in order to efficiently manage water resources for Agriculture, Human Consumption and drought control.

\subsection{Transportation}

Transportation sector has been one of the major contributors to the Greenhouse gas problem around the world and more so in Nigeria because the level of poverty has frequently compelled Nigerians to purchase and use automobiles that 
produce great amount of tail-pipe emissions The Mass Transit system is also a major contributor to high level of tail-pipe emission in Nigeria.

Therefore Government should design efficient mass transportation systems to curtail excessive use of personal automobiles in order to reduce Tail-Pipe emissions [8]. This Mass transit system can be designed to run on gas or bio diesel. Efforts at rehabilitating rail transport should intensify.

\subsection{Environment}

Given the fact that Environment is everything and everything and everything happens in an environment, the Ministry of Environment in Nigeria needs to be more proactive in its operations by designing policy upgrades which promotes holistic environmental sustainability with sector by sector mandates to be handed down to every sector of the economy and adequately enforced for total success [9].

In the short term, home grown plans to reduce green house gases and preserve Biodiversity should be made. Intensive Afforestation and Reforestation should be pursued with set global environmental standards. In the long term, a comprehensive environmental data acquisition exercise should be embarked upon and the result should be used to formulate concrete environmental reparation programs which can be table before Global Funding Agencies like the global environmental facility (gef fund) in order to secure matching fund for practical implementation.

\subsection{National Planning}

The Ministry of National Planning should take the lead in providing direction for all planners in the country to upscale design parameters so as to cater for possible flash point in environmental events; especially for Housing and settlement development (such as New Towns), Road Infrastructure, Water and Sanitation delivery etc [10].

\section{CONCLUSION}

Environmental Impact Assessment regulation should be strengthened while enforcement should be ensured on all categories of development. More importantly, since mankind has discovered that all the substances that were misused by Man to cause and sustain Global Warming on Earth are chemicals, it will therefore be beneficial if man focuses more attention on development of energy sources whose chemicals are environmentally friendly, global warming problem will be solved. This is the basis of responsible geochemistry. The Academia should occupy its traditional driver's seat and provide direction for Political legislation so that Governments would be compelled by law to undertake man's singular most important assignment- the sustainable development; which is the only way to guarantee a sustainable environment for the future of Planet Earth and mankind. The Academia should also engage in studies relating to surface temperature reconstruction for some specific mandate periods in the Country. They should also engage in studies to estimate climate sensitivity around the country.

\section{REFERENCES}

[1] Ojo, K. (2000): Social Issues of Sustainable Water supply Management. In Tayo Odumosu et al (Eds.) Social Problems and Social Work in Nigeria, Center for Planning Studies, LASU,

[2] Ojo, O (1977): The Climates of West Africa. Heinemann. London. Pp218.

[3] Ayoade, J.O (1995): Climate and Human Welfare. Inaugural lecture delivered at the Dept. of Geography, University of Ibadan, Nigeria.

[4] Ojo, A.O (1988) Urbanization and Thermal Problems in Tropical Cities: The Lagos Experience, in Sada P.O and Odemerho, F.O (Eds). Environment? Ital Issues and Management in Nigeria.

[5] Kankara, I. A. (2008). Environmental Sustainability In Africa: An Assessment of Sustainable Access to Safe Drinking Water in the Continent. A paper presented at National Conference of Social Sciences, held at University of Maiduguri, 28/11/2008.

[6] Ladan, I. (2014) Environmental Sciences, a lecture series for 400 Level Students, Al-Qalam University Katsina.

[7] Pinker, R. T., G. Pandithurai, B. N. Holben, O. Dubovik, and T. O. Aro, (2001). A dust outbreak episode in sub-sahel West Africa. J. Geophys. Res., 106, No. D19, 22,923-22,930. https://doi.org/10.1029/2001jd900118

[8] Kankara, I. A. and Kabir, I. (2014). Examining Carbon Sink-Controlled Climate Change Potentiality in Nigeria. A paper presented at the Annual International Conference on Possible Impacts of Climate Change on Africa, held between $18^{\text {th }}$ to $20^{\text {th }}$ May 2014, at the Institute of African Research and Studies, Cairo Universiy. Published in the Book of Proceedings.

[9] Bako, M.; A. Ibrahim; Kankara, I. A.; R. Tukur, G. K.Adamu; Maiwada, N. (2014) An Assessment of Vegetation Dynamics within the Borgu Sector of Kainji Lake National Park, Nigeria. FUDMA Journal of Agriculture and Agricultural Technology (JAAT) Federal University Dutsin-Ma, Volume 1: No. 1.

[10] Bako, M.; A. Ibrahim; Kankara, I. A.; R. Tukur, G. K. Adamu; Maiwada, N. (2015) An Assessment of Vegetation Diversity and Its Potential on Carbon Sequestration In Borgu Sector of Kainji Lake National Park, Nigeria. Journal of Sciences, Ahmadu Bello University Zaria, Nigeria. Vol. 6. No. 7, pp 56.

[11] Bako, M.; A. Ibrahim; Kankara, I. A.; R. Tukur, G. K. Adamu; Maiwada, N. (2015) An Assessment of Vegetal Cover Transition In The Zugurma Sector of Kainji Lake National Park, Nigeria. FUG Journal of Agriculture (FJA) Federal University Gashua, Volume 1: No. 1. 